\title{
Revisionisme Sejarah Jepang terhadap Peristiwa Pembantaian Nanjing
}

\author{
Ni Putu Rianti Sukma Nanda', Joko Purnomo² \\ Universitas Brawijaya
}

\begin{abstract}
This study examines Japan's historical revisionism related to the Nanjing Massacre during its 1937 invasion in the People's Republic of China. In 2015, UNESCO's response to include the Nanjing Massacre in the "Memory of the World Register" received backlash from Abe's government, resulting in a budget suspension from Japan. Japan wanted to be seen as a good country, leaving behind its past image as a war aggressor through historical revisionism. Using the concept of Shared Beliefs and Therapeutic Value, this article analyses homogeneous Japanese society that regards the Nanjing Massacre as something the Japanese government should not be apologetic about and the heterogeneous historical facts of the massacre itself. Finding suggests that Therapeutic Value from the denial comes from the failure of the U.S. and its allies to provide a deterrent effect post-WWII that resulted in victimization and melodrama promoted by the Japanese government. The government also uses narratives such as Toa Renmei Ron and Kami no Kuni as the main argument to boost Japanese superiority as a country. However, such revisionist strategy of the Nanjing Massacre is proven a failure to promote peace among the younger generation.
\end{abstract}

Keywords: historical revisionism, Nanjing massacre, Japan-China relationship, sharedbeliefs, therapeutic value

\section{PENDAHULUAN}

Pertanyaan tentang Historical Memory telah memainkan peran penting dalam kebangkitan politik identitas. Kecenderungan sosial dan politik ini dicerminkan dalam dunia akademis di mana studi tentang Historical Memory telah menyapu sejumlah disiplin ilmu, terutama sejarah, sosiologi, antropologi, dan studi budaya. Historical Memory mengartikulasikan klaim tentang sifat identitas politik karena menjelaskan tentang fokus kontemporer sebuah negara dan latar belakang motivasi. Sejarah telah dibentuk dan dimobilisasi untuk membenarkan proyek-proyek politik saat ini, baik dalam nama penentuan nasib suatu gerakan politik atau etnis, dalam tuntutan keadilan, atau untuk mengajukan klaim legitimasi rezim baru. Historical Memory pada saat ini berjuang dalam porsi penting di dalam komponen besar politik (Duncan Bell, 2014).

Sejarah Pembantaian Nanjing, subjek yang sangat kontroversial dan juga sensitif secara politik dan moral, telah dipolitisasi secara luas. Menetapkan standar yang adil dan dapat diterima secara internasional untuk menilai apakah monograf tentang peristiwa masa lalu dari konflik transnasional dipolitisasi atau tidak adalah pertanyaan besar. Politisi dimaksud disini adalah manipulasi penulisan sejarah dan pembuatan ingatan untuk tujuan politik atau ideologis yang terang-terangan. Maka pertanyaan besar yang lahir dapatkah tulisan sejarah secara objektif merupakan keahlian para profesional sejarah atau apakah ini merupakan produk subjektif para sejarawan yang sedikit banyak dipengaruhi oleh unsur-unsur moral, politik, atau ideologis? (Wei, 2008).

Pada tahun 1937 Jepang meluncurkan invasi skala besar ke China sebagai awal Perang Dunia di Asia. Salah satu penaklukkan terburuk dalam sejarah yaitu pembantaian Nanjing telah menelan ribuan korban jiwa. Implikasi kekejaman di masa lalu ini membuat masyarakat 
Jepang modern saat ini kesulitan untuk mengakuinya, termasuk para cendekiawan dan diplomat (Stockton, 2019). Jepang secara brutal membunuh ratusan ribu orang termasuk tentara dan warga sipil di kota Nanjing, China. Sebanyak 80.000 wanita mengalami pemerkosaan, perburuan tentara China dan ribuan warga sipil dieksekusi. Tentara Jepang juga menjarah dan membakar sepertiga kota Nanjing. Angka dan istilah pembantaian masih diperdebatkan kedua belah pihak Jepang dan China hingga saat ini (History.com Editors, 2009).

Pembantaian Nanjing oleh Jepang merupakan kejahatan perang yang dilakukan agresor perang pada saat perang dunia kedua. Sejarawan Inggris Edward Russel bahkan menyamakan tentara Jepang dengan kekejaman Genghis Khan. Kedutaan Jerman di China yang saat itu masih berafiliasi dengan Nazi menulis kepada Berlin bahwa telah terjadi kekejaman dan aksi kriminal oleh seluruh pasukan yang setara dengan bestial machinery (Transnoodle, 2017). Ingatan tentang pembantaian Nanjing menjadi pusat perselisihan antara China dan Jepang hingga saat ini. Pada faktanya mayoritas masyarakat Jepang mengesampingkan peristiwa sejarah. Sedangkan China mulai mengamplifikasi kebrutalan Jepang di masa lalu. 80 tahun relasi Jepang dan China peristiwa Nanjing masih menjadi jurang besar di hubungan kerjasama bilateral kedua belah pihak.

Klaim Jepang melakukan Revisionisme Sejarah terbukti pada sejarah perpolitikan Jepang yang tidak kondusif dan jujur mengenai kekejaman perang dunia. Mereka memilih untuk mengabaikan isu atau membalas dengan jalan revisionis. Jepang berupaya menghapus korban perang dari sejarah mereka karena tidak nyaman untuk ditunjukkan ke publik. Sensor oleh pemerintah mengenai kekejaman mereka bisa berdampak sensitif terhadap korban seperti Korea, China, dan negara-negara Asia lainnya (Birdwhistell, 2017). Pada tahun 1990an terdapat peningkatan aksi revisionisme sejarah yang menyangkal penggambaran Jepang sebagai aggressor perang dunia. Upaya mengorganisir simposium, menerbitkan kartun dan bacaan populer termasuk membuat New History Textbook. Kasus ini dipelopori Tsukuru Kai yaitu komunitas reformasi buku sejarah Jepang dimulai pada tahun 2001 dan politisi Liberal Democratic Party (LDP) di tingkat nasional dan lokal bergabung dengan komunitas ini.

Pada tahun 2006 Beijing dan Tokyo melakukan Joint Programme yaitu penelitian bersama yang melibatkan sejarawan. Bentuk kerjasama ini adalah kedua belah pihak memutuskan untuk menulis artikel paralel sampai pada tahun 2009. Kedua belah pihak menggunakan kata "agresi" untuk menggambarkan invasi Jepang dan secara eksplisit mengakui viktimisasi Jepang terhadap Tiongkok. Program ini dilabeli sebagai fase pertama dari kerja sama sejarah bilateral (He, 2013). Hal penghambat diskusi kedua belah pihak adalah faktor Perang Dingin dan Mao Zedong. Mao tidak menekan Nanjing sebagai masalah utama dalam hubungannya dengan Jepang yang saat itu menghadapi Amerika. Pada 1980-an China mulai menekankan catatan kejahatan perang Jepang secara nasional setelah Revolusi Budaya Mao berakhir. Urgensi pembantaian Nanjing meningkat seiring dengan interpretasi politik untuk menekan Jepang di tahun 1980 (Mitter, 2017).

Salah satunya kampanye pendidikan. Kurikulum baru sejarah di sekolah menyoroti Perang Sino-Jepang pada tahun 1937-45. Kampanye pendidikan patriotik memuncak pada 1995, ketika Beijing meluncurkan kampanye peringatan yang kuat untuk peringatan 50 tahun kemenangan Tiongkok terhadap Jepang (He, 2013). Gelombang tekanan masyarakat China terhadap Jepang meningkat di tahun 2012. Demonstrasi Anti Jepang menyangkut masalah Pulau Senkaku dan sejarah penaklukan Manchuria untuk memboikot produk Jepang dan menyerang kantor perwakilan Jepang di China (Johnson \& Shanker, 2012). Shinzo Abe berpendapat China berupaya menghalangi posisi Jepang di mata internasional dengan menuding demonstrasi merupakan hasil masalah domestik. Upaya penangkalan terhadap tekanan China untuk membicarakan sejarah Nanjing tercermin dalam sikap pengabaian 
masalah (New York Times, 2005). Pada tahun 2017 kembali terjadi protes masyarakat China di Jepang karena presiden APA Group Toshio Motoya menulis buku yang menyangkal Nanjing dipamerkan di seluruh hotelnya (Reuters, 2017).

Hubungan Jepang dan China terbilang tidak terlalu stabil di kawasan Asia Timur, banyak kerjasama ekonomi dan politik tersendat akibat reaksi sensitif kedua belah pihak menanggapi histori perang. Shinzo Abe dengan aksi kontroversial membuat Beijing marah dengan mengunjungi Kuil Yasukuni pada tahun 2013. Kuil ini dibangun untuk mengenang pahlawan Jepang yang gugur dalam perang termasuk penjahat perang yang membantai warga China pada Perang Pasifik (Johnson, 2019). Sejarah selalu menjadi inti dari cara berpikir nasional dan gagasan tentang bangsa termasuk nasionalisme. Begitupun Jepang idealismenya sebagai 'Kami no Kuni' yaitu Negara Dewa. Salah seorang pemegang sentral Jepang pada dekade terakhir adalah perdana Menteri Shinzo Abe. Tokoh kunci dalam perkembangan Gerakan revisionisme historis menyangkut pengabaian pembantaian Nanjing (Sven Saaler, 2016). Kepentingan nasional Jepang saat ini adalah menarik kerjasama dan hubungan lebih dekat dengan Amerika Serikat dan sekaligus menunjukkan perannya dalam World Order di abad ke-21. Kepentingan ini terkait dengan relasi China-Jepang-Amerika yang rumit terkait masalah geopolitik dan keamanan yang terjadi di kawasan Asia Timur (In Japan's National Interest - Policy Forum , 2017). Dalam pemerintahan Abe, Jepang memulai merangkul AS dengan strategi anti-China dan upaya peremajaan Jepang lewat revisi konstitusi.

China berpendapat bahwa pemimpin Jepang memiliki hak untuk menumbuhkan patriotisme di kalangan muda. Penanaman revisionisme historis dalam agenda pasifisme yang dianut secara global demi membuat generasi baru yang bebas dari tanggung jawab aggressor perang (Teo V, 2019). Awalnya, istilah "Revisionisme Sejarah" memiliki silsilah kontroversial. Penghapusan "comfort women" dan pembantaian Nanjing adalah contoh nyata dari revisionisme bermotivasi politik. Namun merevisi sejarah dapat menjadi upaya positif maupun negatif, tergantung apakah kepentingan saintifik atau politik yang melatarbelakangi. Sehingga dalam tulisan ini makna Revisionisme yang dilakukan Jepang dengan motivasi politik melalui penolakan keabsahan pembantaian pembantaian Nanjing memiliki konotasi negatif. Revisionisme negatif bertujuan untuk menutupi praktik-praktik negara yang paling gelap terutama terjadi pasca perang dunia kedua menutupi kejahatan perang demi membuat citra baik pada abad ini (Suny, 2015).

Penulis melihat urgensi Revisionisme Pembantaian Nanjing lebih perlu disoroti dibanding isu besar lain seperti sengketa Senkaku dan Comfort Women dikarenakan tidak adanya pernyataan eksplisit pemerintah Jepang terhadap posisinya dalam masalah ini. Jepang menyadari pembantaian ini mengotori mitos 'Kami no Kuni' yaitu tanah suci. Sehingga berbagai upaya dilakukan demi membuat citra Jepang menjadi bersih walaupun menempuh kebijakan kontroversial dan bahkan radikal cukup beresiko tinggi. Dasar argumen ini menunjukkan mentalitas superior kekaisaran Jepang dan inferioritas yang diilustrasikan oleh kengerian kolonialisme Jepang dengan alasan melindungi Asia dari Westernisasi. Hal ini tak berubah hingga saat ini melihat semangat nasionalisme tinggi dari Shinzo Abe bersama Liberal Democratic Party (LDP) untuk melakukan Revisionisme Sejarah (Suny, 2015). Pada Oktober 2015, United Nations Educational, Scientific and Cultural Organization (UNESCO) menanggapi secara positif aplikasi China untuk memasukkan dokumen yang dipersengketakan yaitu Pembantaian Nanjing dalam "Memory of the World Register". Tetapi juga menimbulkan pertanyaan tentang otoritas moral UNESCO dalam mempromosikan kesadaran publik akan dokumen-dokumen sejarah sebagai warisan bersama semua umat manusia (Nakano, 2018). Tanggapan Abe tidak hanya menolak aplikasi dan mempertanyakan proses persetujuan tetapi juga melakukan penangguhan kontribusi sumbangan terhadap anggaran UNESCO. 
Tulisan ini bertujuan untuk membuktikan bahwa Jepang berusaha untuk memperbaiki image- nya agar bisa dianggap sebagai bangsa yang baik. Jepang berusaha menghapus title agresor perang dengan cara membuat generasi baru yang bebas dari tanggung jawab perang. Strategi ini muncul dikarenakan kebangkitan Nasionalisme sayap kanan konservatif dipimpin oleh Shinzo Abe. Implikasi strategi berdampak pada relasi ChinaJepang-Amerika dalam masalah geopolitik kawasan Asia Timur. Revisionisme Sejarah dianut oleh komunitas Homogen Jepang dengan therapentic value mengalami konflik sosial dengan Masyarakat Heterogen Asia Timur mencangkup China dan Korea. Upaya pembebasan tanggung jawab atas kejahatan perang demi mendukung agenda baru Jepang yang aktif di kancah Internasional melalui relasi dengan Amerika.

\section{KERANGKA PEMIKIRAN}

Sven Saaler dalam jurnalnya yang berjudul "Nationalism and History in Contemporary Japan" yang menjadi rujukan studi terdahulu, menitikberatkan pada kata kunci Nasionalisme Jepang dan berdasar pada budaya serta spiritualitas Kami no Kuni' melekat pada semua sendi masyarakat dan perpolitikan di Jepang. Tulisan ini membahas rezim Jepang pasca perang dunia yang melihat aksi agresi terdahulu sebagai noda terdahulu dalam sejarah dan menjustifikasi aksi Revisionisme Sejarah sebagai usaha memperbaiki citra agresor di Perang Pasifik. Sasaran utama dari Revisionisme Sejarah adalah sistem pendidikan sekolah di Jepang secara khusus yaitu buku pelajaran sejarah. Titik berat dari tulisan ini adalah adalah aktor revisionis yang memulai gerakan revisonisme sejarah pada tahun 1990-an adalah Shinzo Abe sebagai perdana Menteri. Peran Abe sangat signifikan karena didorong motivasi agenda neonasionalis dan kerap kali membawa isu pasca perang dunia.

Dalam tulisan Sven Saaler juga dijelaskan beberapa aktor yang memiliki kedekatan dengan Abe, sama-sama nasionalis dari kalangan pengusaha, media sampai politikus berusaha mengagendakan revisionisme sejarah kepada masyarakat Jepang dengan berbagai cara. Persamaan yang terdapat pada tulisan Sven dengan Revisionisme Jepang yang saya tulis yaitu mengacu pada titik kebangkitan Nasionalisme dan nilai yang dijunjung budaya Jepang beribu tahun lamanya. Perbedaannya terdapat pada konsep dan perspektif yang digunakan, tulisan Sven hanya menulis dari pandangan domestik tanpa keterlibatan aktor internasional.

Jurnal kedua yaitu Forgiving The Culprits: Japanese Historical Revionism in a Post-Cold War Context oleh Ingyu Oh dan Douglas Ishizawagrbic. Fokus kajian ini lebih banyak menjelaskan tentang Revisionisme Sejarah termasuk definisi, tujuan, alasan dan logika apa yang melatarbelakangi Jepang memilih strategi ini. Kata kunci yang sama juga dibawakan yaitu nasionalisme sebagai motif justifikasi tindakan saat perang pasifik. Secara luas jurnal Douglas memiliki kesamaan dengan judul tulisan saya, namun perbedaan terletak pada tahun dan fokus bahasan yang luas termasuk jangka waktu dan ragam. Jurnal ketiga yaitu Politics of Memory, Historical Revisionism, and Negationism in Postsocialist Serbia by Marco Škorić \& Milivoj Bešlin menjelaskan studi kasus Revisionisme Sejarah yang terjadi di Serbia dengan karakterisasi penghapusan ingatan pasca perang Yugoslavia, demonisasi sosialisme dan sampai langkah ekstrem penulisan ulang sejarah termasuk pengakuan sebagai korban perang yang tampaknya memiliki pola yang mirip dengan apa yang Jepang lakukan. Jurnal Skoric menjelaskan pemahaman mengenai revisi sejarah secara positif dengan orientasi pengetahuan murni atau revisionisme dilatarbelakangi dengan kepentingan politik melalui tata cara. Penjelasan tentang nilai yang dibawah dalam upaya revisionisme budaya, akibat, dan aktor yang juga disebutkan mempengaruhi jalannya revisionisme sejarah. Persamaan yang dimiliki jurnal Skoric dengan penelitian milik penulis yaitu konsep Historical Revisionism oleh 
Tucker. Perbedaannya terdapat pada studi kasus yang digunakan yaitu Serbia pasca perang Serbia sedangkan penulis menggunakan Jepang pasca perang pasifik.

\section{Revisionisme Sejarah}

Definisi mengenai Revisionisme Sejarah masih diperdebatkan karena bisa mengacu pada proses pemeriksaan ulang secara skolastik terhadap pengetahuan yang sudah ada atau bisa berarti diskorsi ilegal catatan sejarah mencangkup penyangkalan atas kejahatan historis yang disebut sebagai negasionisme. Revisionisme sejarah yang sah menggunakan sejarawan (Historians) untuk mencari kebenaran sesungguhnya tetapi 'revisionist historians' mengkapitalisasikan kredibilitas mereka untuk mempromosikan pseudohistory sebagai kebenaran (Gutenberg, 2019). Sedangkan revisionisme historis tidak sah/negasionisme berarti menemukan kebenaran yang berbeda agar sesuai dengan konteks politik, sosial, atau ideologis yang dibutuhkan (Gutenberg, 2019).

Konsep "Illegitimate Revisionisme Historis" adalah frasa yang menggambarkan proses yang mencoba menulis ulang sejarah dengan meminimalkan, menyangkal, atau sekadar mengabaikan fakta-fakta penting. Debat revisionis menunjukkan pentingnya sejarah sebagai elemen kunci dalam perjuangan politik saat ini. Definisi lain Eduard Bernstein pada tahun 1899 memahami revolusi kekerasan antar kelas melalui paham Marxis. Sementara bentuk sosialis dari revisionisme berhubungan langsung dengan teori politik dan ekonomi, yang dimana mempunyai pengaruh besar dalam studi perkembangan sejarah yang disebut sebagai "bistory from below". Definisi lain yang berhubungan dengan rezim suatu negara yaitu upaya yang mencoba mengatakan bahwa kekejaman perang tidak terjadi atau pelakunya harus dimaafkan. Contohnya seperti penyangkalan Holocaust, penyangkalan "genosida" Turki terhadap orang-orang Armenia, dan kekejaman Jepang dan kejahatan perang selama Perang Dunia II (“Revisionist History,” 2021).

Dalam sejarah perkembangan Revisionisme Sejarah, munculnya istilah Denialisme sejarah dianggap memiliki arti yang sama. Denialisme Sejarah merupakan aksi penolakan dialog metodologis menitikberatkan pada masalah genosida, kejahatan atas kemanusiaan dan kejahatan perang untuk menyebar informasi. Tetapi perbedaan dengan Revisionisme Sejarah terletak pada penentuan undang-undang atau pengadilan domestik maupun internasional. Di Eropa hukum Memory Law/Remembrance Law menetapkan Denialisme Sejarah sebagai tindakan kriminal. Akar dari Denialisme sendiri adalah rasisme yang mempengaruhi pemikiran publik. Kebanyakan pengadilan dan pengakuan bentuk kriminal terjadi di Negara demokratis Eropa (Fronza, 2018). Maka dapat dilihat Revisionisme Sejarah tidak sah dilatarbelakangi nasionalisme dan propaganda sedangkan Denialisme dari rasisme. Perjuangan atas narasi nasional sering diperjuangkan, seperti yang diamati oleh Yoshiko Nozaki, dalam tulisannya mengenai kontroversi buku teks Jepang tentang 'wanita penghibur dalam' Perang Asia-Pasifik (1931-34). Revisionisme historis yang ditemani politik kulturalis adalah versi kontemporer dari politik sejarah yang dijelaskan oleh Nozaki. Ketika suatu kelompok menggunakan masa lalu untuk menyediakan bahan baku bagi strategi politik baru, interpretasi baru ini kemungkinan sedikit memperhatikan fakta sejarah sesungguhnya, karena peristiwa dan detail rinci tidak diperlukan dalam 'narasi' baru ini maka mereka mengedit atau bahkan mengubah untuk menceritakan kembali versi baru (Butterworth G, 2007).

Revisi pada hakikatnya adalah sebuah kegiatan positif yang membuka jalan melihat sejarah sebenarnya secara tepat tetapi jika diiringi oleh kepentingan politik dan motivasi ideologi adalah konotasi negatif. Sejarah sebagai sebuah ilmu memiliki sedikit masalah dalam menarik garis pembatas antara sejarah yang benar-benar terjadi dengan bentuk denial/revisi/negasi sejarah. Tujuan utama revisi adalah membuat tidak seorang pun paham betul mengenai 'kebenaran' kejadian sejarah karena telah menjelma menjadi banyak 
kebenaran dengan berbagai perspektif. Efek dari revisi sejarah adalah grup dominan menekan grup minoritas dengan cara tidak dihiraukan berkepanjangan. Tujuan untuk memenuhi kepentingan politik dan motif dibimbing oleh 'therapeutic values' dimana menawarkan pengikutnya ketenangan psikis kepuasan untuk menyatukan individu. Aktor utama dalam Revisi biasanya melakukan upaya penulisan dibumbui motif tersebut.

Nilai-Nilai yang menyangkut Revisionisme Budaya termasuk penolakan sebagai terdakwa (the denial of historical guilt) contohnya Holocaust, promosi penghormatan kepada diri sendiri (the promotion of self-respect) seperti bentuk mitos nasional dan eliminasi rasa alienasi dan ketidakjelasan (the elimination of a sense of alienation and absurdity) sebagai contoh conspiracy theories. Pelaku Revisi tidak mencari bukti yang menghasilkan kesimpulan tetapi lebih kepada mencari bukti yang cocok dan mendukung ideologi mereka bisa dikatakan tidak menganalisis keseluruhan dan hanya fokus pada bukti yang tidak konsisten bahkan paham betul mereka melakukan logical fallacies. Dalam tulisan Marko Škorić mengenai Revisionisme Sejarah di Serbia dia melihat karakterisasi dari revisionisme dengan kata kunci pengabaian kontribusi sains, demonisasi, relatisasi sampai menulis ulang masa lalu termasuk penipuan. Marko juga menjelaskan adanya subjek menonjol dalam Revisionisme sejarah (Marko Skoric \& Milivoj Beslin, 2017).

Konsep Revisionisme historis penuh dengan konotasi yang merendahkan dan negatif, sebagaimana dicatat James McPherson dalam artikelnya di American Historical Association "Revisionist Historians". Seringkali konsep ini disamakan dengan pengerjaan ulang narasi sejarah yang disengaja dan berbahaya untuk memunuhi tujuan politik atau ideologis. Upaya ini untuk melemparkan revisionisme historis dalam imej negatif merusak proses penulisan dan penyelidikan sejarah. Sejarawan profesional yang terlibat dalam revisionisme historis sebagai proses penting di lapangan. Konotasi negatif ini mungkin sebagian disebabkan oleh praktik penyangkalan dengan para praktisi yang sengaja menyatukan diri ke dalam aliran pemikiran revisionis untuk berikan kredibilitas pada klaim mereka. Seringkali penyangkalan dan negasi dalam bidang sejarah bersifat menguntungkan diri sendiri, baik karena alasan politik atau ideologis (Herritykm, 2017).

\section{Aviezer Tucker: Historiographic Revision and Revisionism}

Historiografi Revisionis/Revisionist Historiography berbagi dengan historiografi yang merevisi signifikansi historis dan sistem nilai. Namun Revisionist Historiography berbeda dari historiografi yang direvisi karena ia kebal terhadap efek bukti baru. Salah satu strategi revisionis utama adalah "membuat masalah epistemologis menjadi kabur ", untuk membuat perbedaan antara pengetahuan berdasarkan fakta yang mungkin berdasarkan fiksi yang kabur. Ini mengaburkan batas antara kebenaran historiografi dan kepalsuan dengan mengklaim bahwa mungkin ada lebih dari satu narasi historiografi yang "benar" tunggal. Upaya kaum revisionis untuk mengacaukan pengetahuan dengan fiksi didasarkan pada filsafat yang buruk, argumen yang tidak valid dan kesalahpahaman tentang epistemologi kontemporer dan filsafat ilmu pengetahuan. Ketika para sejarawan membuktikan menggunakan bukti dan metode historiografi standar bahwa ada Holocaust, kaum revisionis dapat berselisih dengan standar epistemik dari historiografi arus utama; contohnya dengan mengklaim bahwa bias politik atau etnis dari sebagian besar sejarawan, "keadilan pemenang" mereka, mencegah mereka melihat apa yang oleh kaum revisionis dianggap sebagai "kebenaran" mereka. Poin penting dalam tulisan ini menjelaskan tentang 'Shared Beliefs' diantara komunitas homogen yang berbeda pendapat dengan konsensus historiografi yang dimiliki masyarakat heterogen adalah bias khusus mereka.

Historiografi revisionis biasanya mengandalkan 'therapeutic value' yang menilai proposisi historiografi mempunyai pengaruhnya terhadap kesejahteraan psikologis audiens 
yang dituju. Nilai-nilai terapeutik yang sering digunakan dalam historiografi meliputi: penolakan rasa bersalah sejarah (the denial of historical guilt) dengan menyangkal Holocaust; promosi harga diri (the promotion self-respect) melalui mitos nasional; dan penghapusan rasa keterasingan dan absurditas (the elimination of a sense of alienation and absurdity) melalui teori konspirasi. Upaya ini biasanya diterima oleh komunitas homogen tertentu karena berdasar nilai dan norma mereka. Ketidakkonsistenan antara nilai-nilai terapeutik dan nilai ilmiah memanifestasikan diri mereka dalam konflik sosial antara komunitas terapeutik yang homogen dan anggota komunitas historiografi yang heterogen yang berbagi nilai-nilai kognitif. Perbedaan antara historiografi ilmiah dan nilai terapeutik, antara historiografi yang membuat revisi berdasarkan bukti dan historiografi revisionis yang mengabaikan bukti.

Istilah Revisionisme Sejarah lebih umum digunakan walaupun pada perkembangannya terdistorsi menjadi sebuah strategi politik. Jurnal mengenai Revisionisme Sejarah yang dilakukan Jepang lebih banyak ditemui didukung dengan argumen kebangkitan nasionalisme. Melihat Revisionisme Sejarah sebagai strategi nasionalis dan propaganda pasca perang. Sedangkan Denialisme sendiri diartikan sebuah tindakan kriminal atas konsensus European Union untuk mengadili negara demokratis Eropa berdasar Memory Law/Remembrance Law. Penulis berkesimpulan penerapan konsep Revisionisme Sejarah lebih cocok karena titik berat sejarah sebagai pembentuk semangat nasionalisme. "a political nation forged from a long historical process", dengan identitas "not ethnic but political, historical and cultural" (Cattini, 2011). Perlu diketahui pola pikir revisionisme historis pro-Jepang ini selalu ada dalam politik Jepang, khususnya di dalam Partai Demokrat Liberal. Tetapi dengan kebangkitan LDP dipimpin oleh Shinzo Abe Revisionisme sejarah yang awalnya bermotivasi nasionalisme berubah kearah lebih konservatif di kawasan (Birdwhistell,2017). Dalam penelitian ini menjabarkan upaya Jepang yang menolak dan mengabaikan kejahatan perangnya di masa perang dunia. Relasi hubungan China dan Jepang yang sangat buruk dilatarbelakangi peristiwa sejarah yang kelam salah satunya pembantaian Nanjing. Reaksi Jepang untuk menanggapi tekanan pengakuan tersebut tercermin dengan upaya Revisionisme Sejarah. Masalah ini dapat dianalisis menggunakan konsep Historical Revisionism oleh Tucker.

Salah satu unsur penting dalam Revisionisme adalah bias yang dianut oleh komunitas Homogen dalam wilayah/etnis/negara/kelompok tertentu. Bias ini terlihat jelas ketika ada konsensus mayoritas yang diakui kelompok heterogen. Partai LDP sayap kanan diketuai Shinzo Abe memegang kendali konsensus publik Jepang. Sedangkan kelompok Heterogen memiliki konsensus berbeda dianut oleh korban kejahatan Jepang seperti China dan Korea termasuk Lembaga Internasional yaitu UNESCO. Unsur selanjutnya yaitu Therapeutic Values atau nilai terapis yang bertentangan dengan bukti sejarah saintifik. Nilai terapis ini menyesuaikan dengan keadaan psikologis audiens agar terlepas dari rasa bersalah dan tanggung jawab. Strateginya dengan membangkitkan kepercayaan diri dan rasa kebenaran yang semu. Nilai terapis pertama menyangkut aksi Denial terhadap kesalahan. Jepang melakukan pengabaian dan penolakan diskusi lebih lanjut atas semua tuntutan bermuatan peristiwa Nanjing. Promosi Self-Respect dilakukan dengan latar belakang budaya mitos kuno yaitu jepang sebagai 'Kami no Kuni' atau Negara Tuhan yang seharusnya murni dan tidak pernah tercemar oleh aksi brutal. Mitos ini menyebar dalam sendi masyarakat jepang hingga mengendalikan sistem politik Jepang. Yang terakhir adalah eliminasi perasaan alienasi dengan munculnya teori konspirasi bahwasanya Jepang adalah pelindung Asia dari Westernisasi dan menerima kerugian terbesar saat perang dunia melalui korban bom atom.

Penelitian ini termasuk dalam jenis penelitian penelitian deskriptif. Penulis telah menentukan bahwa unit analisis yang akan penulis gunakan adalah penjelasan deskriptif dimana penulis akan menggunakan variabel dependen yang berimplikasi pada unit eksplanasi yang independen yang dimana unit analisa yang digunakan penulis dalam penelitian ini adalah 
Jepang dan unit eksplanasinya adalah Peristiwa Nanjing (Mochtar Mas'Oed, 1994). Ruang lingkup penelitian ini berfokus pada setiap upaya Revisionisme Sejarah Peristiwa Nanjing oleh Jepang akan berfokus pada pemerintahan Pemerintahan Perdana Menteri Shinzo Abe berkisar pada tahun 2012 (Kabinet Abe kedua) sampai sekarang (Kabinet Abe keempat) yang berhubungan langsung dengan aktivitas LDP partai sayap kanan konservatif terutama pada tindakan yang berhubungan dengan bahasan Nanjing. Teknik yang digunakan dalam tulisan ini adalah studi pustaka (library research). Data yang dikumpulkan bersifat data sekunder seperti buku, jurnal, koran, working paper, laporan termasuk skripsi/tesis/disertasi, ebook dan sumber kredibel lain dari internet. Penulis berfokus kepada kebijakan,tindakan dan agenda pemerintahan yang terjadi dalam kabinet era pemerintahan Shinzo Abe yang bisa dikategorikan sebagai Revisionisme Sejarah.

\section{HASIL DAN PEMBAHASAN}

\section{Kronologi Pembantaian Nanjing}

Invansi Jepang ke China selama Perang Dunia Kedua berlangsung selama 8 tahun dari tahun 1930 an sampai dengan 1945 yang dikenal oleh masyarakat China sebagai "Eight Year War of Resistance". Pembantaian Nanjing adalah bentuk kekejaman terbesar yang dilakukan oleh tentara Jepang menyangkut jumlah korban dan kecepatan pembantaian terjadi. Pada tahun 1937 bulan Juli, tentara Jepang meluncurkan serangan ke kota Beijing yang diikuti invansi skala besar ke daerah Utara China. Tentara China saat itu memiliki pertahanan yang lemah dengan mudahnya didesak tentara Jepang ke Utara menuju Shanghai. Perang berlangsung selama 3 bulan dan akhirnya Shanghai jatuh ke tangan Jepang dan menuju Barat Laut pusat pemerintahan China pada saat itu yaitu kota Nanjing.

Sekitar 100,000 tentara Jepang memasuki kota Nanjing pada 13 Desember 1937 tanpa perlawanan besar karena tantara China banyak telah terevakuasi. 7 minggu setelahnya sekitar 350,000 orang termasuk ratusan tentara China yang tak bersenjata secara sistemik mengalami pembantaian menggunakan bayonet, senjata, machine gun, dan granat. Beberapa dari mereka dibakar hidup-hidup atau bahkan dikubur untuk latihan bayonet. Selama 39 hari $1 / 3$ bagian dari kota Nanjing terbakar oleh api. Selama periode tersebut ada pebisnis asing dan misionaris dari Eropa dan Amerika menetap di kota itu. Selama invasi dan pembantaian pendatang asing memutuskan untuk tetap tinggal demi melindungi masyarakat China dengan mengorganisir Komite Internasional. Komite ini membentuk Nanking Safety Zone yaitu area seluas $3.8 \mathrm{~km}$ persegi yang mencangkup kedutaan Amerika, Universitas Nanjing dan University Art and Sciences Nanking untuk perempuan (Ginling College). Komite Internasional ini memancing pemerintah Jepang untuk mengakui zona tersebut tetapi tanpa keberhasilan. Tentara Jepang bahkan membunuh penduduk lokal China termasuk perempuan, anak dan orang tua di depan anggota Komite Internasional.

Tentara Jepang mengamuk di kota Nanjing mengikuti peraturan pembantaian yang dikenal sebagai "The Three Alls- Rape All, Loot All and Burn All". Ada saksi yang mendokumentasikan kejadian yang menceritakan kembali kengerian kepada sejarawan dan penulis seperti Iris Chang. Selain membantai orang-orang China, Jepang bahkan ingin mencuri warisan leluhur mereka. Kerugiannya cukup besar mencangkup 897,178 jilid buku klasik dari perpustakaan pusat dan privat Nanjing. Buku itu sekarang berada di Jepang, menjadi perpustakaan terbaik mempelajari budaya Asia. 
Tabel 1. Kronologis Pembantaian Nanjing

\begin{tabular}{|c|c|}
\hline Tanggal & Peristiwa \\
\hline 18 September 1931 & $\begin{array}{l}\text { Setelah peristiwa Mukden, Jepang menaklukan Manchuria lalu } \\
\text { membangun Manchukuo }\end{array}$ \\
\hline Awal 1937 & $\begin{array}{l}\text { "Marco Polo Bridge Incident" Invasi skala besar tentara Jepang } \\
\text { dimulai.Pesawat Jepang mulai menjatuhkan bom di Nanking lebih dari } \\
100 \text { buah }\end{array}$ \\
\hline 7-9 Juli 1937 & $\begin{array}{l}\text { Perang antara Tentara Revolusi Nasional republik China dan Tentara } \\
\text { Kekaisaran jepang }\end{array}$ \\
\hline 13 Agustus 1937 & Jepang menyerang Shanghai \\
\hline 15 Agustus 1937 & Serangan udara pertama di Nanjing \\
\hline 25 September 1937 & $\begin{array}{l}\text { Pengeboman paling mengerikan terjadi. } 500 \text { bom dijatuhkan } \\
\text { membunuh } 600 \text { penduduk Nanjing termasuk mengenai kamp } \\
\text { pengungsian,stasiun radio,pusat energi,pengolahan air dan rumah sakit }\end{array}$ \\
\hline 12 November 1937 & Shanghai jatuh \\
\hline 15 November 1937 & Pemerintahan Chiang Kaishek dimulai \\
\hline 16 November 1937 & Komite Internasional Nanking untuk Safety Zone dibentuk \\
\hline
\end{tabular}

20 November 1937 Kekuatan Jepang mulai memasuki Nanjing dan kota menjadi kacau

22 November 1937 Proposal Safety zone dikirim ke otoritas Jepang, ditolak

3 Front terbentuk oleh tentara kekaisaran Jepang : front timur berada sepanjang jalan shanghai menuju nanjing. Front Tengah adalah jalan dari Nanjing ke Hangzhou dan Front Barat mulai dari 23 November 1937 Changde,Xuandcheng dan Wuhu melingkari Nanjing 


\begin{tabular}{|l|l|}
\hline 25 November 1937 & $\begin{array}{l}\text { John Rabe menghubungi Hitler meminta tolong membangun Safety } \\
\text { Zone }\end{array}$ \\
\hline 8 Desember 1937 & Chiang Kaishek dan penasehat melarikan diri \\
\hline 10 Desember 1937 & $\begin{array}{l}\text { Jepang menunggu bendera menyerah tapi tidak ada yang hadir maka } \\
\text { serangan dimulai }\end{array}$ \\
\hline 13 Desember 1937 & $\begin{array}{l}\text { Tentara Jepang dibawah komando Jendral Iwane Matsui menguasai } \\
\text { kota menandai fase 1 penyerangan }\end{array}$ \\
\hline $14-21$ Desember & $\begin{array}{l}\text { Tank dan artileri batalion sampai di Nanjing. Instruksi kepada tentara } \\
\text { Jepang untuk "Kill all, Rape all, Loot All'Pemerkosaan, penjarah dan } \\
\text { pembunuhan } \\
\text { adalah gelombang besar kekerasan }\end{array}$ \\
\hline 21 Desember 1937 & $\begin{array}{l}\text { Tentara Jepang memulai gelombang kedua kekerasan. Banyak } \\
\text { pembunuhan dilakukan di sepanjang sungai Yangtze }\end{array}$ \\
\hline 28 Jan.-3 Feb. 1938 & $\begin{array}{l}\text { Gelombang ketiga kekerasan. Dunia mengetahui Pembantaian Nanjing } \\
\text { tapi tidak mengetahui derajat kekerasan yang dilakukan. Mayat warga } \\
\text { Nanjing } \\
\text { dikubur atau dibakar di kuburan masal }\end{array}$ \\
\hline
\end{tabular}

\begin{tabular}{|l|l|} 
Mei 1938 & Safety Zone lebur dan bantuan berlanjut \\
\hline
\end{tabular}

Pasca pembantaian Nanjing terjadi, Jepang menyerah tanpa syarat pada 2 September 1945. Amerika Serikat dan sekutu berencana untuk menghukum Jepang atas segala tindak kriminal pelanggaran hak asasi manusia, kejahatan perang dan kejahatan terhadap perdamaian. Dasar untuk Tokyo War Crimes Trials adalah International Military Tribunal for the Far East (IMFTE) telah mengadakan beberapa kali konferensi perang dimulai dari Kairo tahun 1943. Sidang yang sama sudah diadakan di Nuremberg, Jerman atas tindakan kriminal Nazi. General Douglas MacArthur membuat IMFTE yang lebih sering disebut sebagai Tokyo War Crimes Tribunal pada tahun 1946. 11 negara berpartisipasi dalam sidang 28 orang Jepang sebagai terdakwa terdiri dari 9 masyarakat sipil dan 19 pegawai militer berlangsung Mei 1946 sampai dengan November 1948. Persidangan ini sangat dipengaruhi kondisi Perang Dingin saat itu, adanya penutupan terlalu dini dan batasan individual dalam mencari bukti. Hal ini mengakibatkan munculnya tahap awal penolakan Jepang terhadap rasa bersalah atas tindakan kriminal yang dilakukan tentara kekaisaran Jepang hingga saat ini (Cervi, 2010).

\section{Implikasi terhadap Jepang}

Alasan Jepang melakukan Revisionisme Sejarah terhadap kejahatan perang terbesarnya di China menyangkut hubungan historis kedua belah pihak. Dinamika hubungan 
antara Jepang kepada China inilah yang melatarbelakangi urgensi keputusan pengabaian fakta sejarah. Hubungan bilateral antara kedua negara bisa dikatakan cukup konfliktual yang memiliki kemungkinan dampak signifikan pada perdamaian, stabilitas, dan kemakmuran Asia Timur. Secara historis hubungan Jepang dan China telah terjalin lebih dari dua milenia. Dalam tulisan ini secara rinci akan dijelaskan hubungan antara Jepang dan China dalam 44 tahun setelah normalisasi relasi diplomatik mereka pada tahun 1972. 44 tahun hubungan terbagi menjadi 4 perbabakan secara kronologis yaitu pada tahun 1972-1982, 1982-1992, 1992-2002, dan 2002-2016. Periode-periode ini dipilih berdasar pada perubahan kongres Chinese Communist Party (CCP) setiap 5 tahun sekali.

Periode pertama pada tahun 1972-1982 adalah periode dimana faktor-faktor politik dan ekonomi merupakan prioritas tinggi bagi Jepang dan masalah internasional maupun keamanan penting bagi pandangan China. Pada kurun tahun ini adanya peningkatan hubungan antara kedua belah pihak, terutama setelah jatuhnya kekuatan sayap kiri dalam politik China. Pada sisi persepsi dan emosi publik berperan besar dalam mempromosikan hubungan selama 10 tahun pertama setelah normalisasi, tetapi dengan alasan yang berbeda di masing-masing pihak. Publik tampaknya lebih memahami dan tidak takut terhadap sosialisme terutama bentuk-bentuk sosialisme di Asia, yang dipahami dalam konteks nasionalisme anti kolonial. Faktor terbesar dalam perkembangan hubungan Tiongkok-Jepang pada periode ini adalah pengaruh lingkungan internasional.

Periode selanjutnya pada tahun 1982-1992 dimana persepsi orang tentang kedua belah masing-masing pada umumnya bersifat hangat dan positif. Reformasi dan kebijakan pembukaan China berangsur-angsur berkembang dan kontribusi Jepang terhadap ekonomi Tiongkok sangat dihargai oleh China. Pada rentang tahun ini adalah era kebangkitan Jepang dan para pemimpin China kembali menyatakan keprihatinan mereka tentang remiliterisasi Jepang ("Definition of remilitarization," 2021). Upaya remiliterisasi Jepang kebanyakan mengambil isu-isu seperti buku teks sejarah dan kunjungan perdana Menteri ke Kuil Yasukuni (simbol militerisme Jepang ke China dan Korea). Pada sisi lain perkembangan China tetap tidak stabil, seperti yang ditunjukkan oleh Insiden 4 Juni.

Periode antara tahun 1992-2002 mampu mengantarkan era baru hubungan Tiongkok-Jepang karena adanya perubahan internal yang drastis baik Jepang maupun China. Jepang mengalami "bubble economy" pada awal 1990-an, diikuti kalahnya kekuatan partai politik nasional yaitu LDP (1955-1993). Sisi lain China Deng Xiaoping melakukan kunjungan ke negara selatan pada tahun 1992 menyebabkan perubahan dalam politik China. Semua faktor ini mendorong hubungan politik China-Jepang menurun setelah memuncak dengan kunjungan Kaisar tahun 1993, sementara hubungan ekonomi mereka memasuki tahap perkembangan yang lebih tinggi. Periode ini mengalami peningkatan yang dapat diidentifikasikan dalam konteks nasionalisme di beberapa bagian masyarakat Jepang.

Terkait dengan masalah sejarah di antara kedua belah pihak politisi Jepang agaknya lebih terbuka dengan mengakui dan meminta maaf atas invasi yang dulu dilakukan. Pada tahun 1993 Perdana Menteri Hosokawa Morihiro menyatakan penyesalannya dan menawarkan permintaan maaf untuk "tindakan agresi dan pemerintahan kolonial," sementara Perdana Menteri Murayama Tomiichi mengeluarkan 'Murayama Statement' yang terkenal pada tahun 1995 dimana ia menguraikan penyesalan bangsa dan permintaan maaf ("MOFA: Statement by Prime Minister Tomiichi Murayama 'On the occasion of the 50th anniversary of the war's end' (15 August 1995)," 2021). Pengeditan buku teks sejarah revisionis yang baru dapat ditafsirkan sebagai gerakan kontra mengganggu perkembangan relasi oleh masyarakat konservatif. Para cendekiawan neokonservatif tidak puas dengan efek negatif dari marketisasi seperti penurunan kontrol dan otoritas pusat, meningkatnya korupsi 
dan kesenjangan pendapatan. Para neokonservatif menemukan solusi dengan menggunakan nasionalisme melalui stimulasi adanya pencemaran sejarah.

China menanggapi reaksi nasionalisme Jepang dengan solusi yaitu "Pendidikan Patriotic". Meskipun pendidikan patriotik sebenarnya tidak bertujuan untuk menanamkan citra antisipasi negatif terhadap orang Jepang tetapi hasil itu yang didapatkan. Program siaran berulang yang menampilkan perang melawan Jepang terutama pada musim panas 1995 untuk memperingati ulang tahun kelima puluh akhir Perang Dunia II, berdampak besar pada masyarakat China terutama mayoritas yang tak mengetahui perang sebenarnya membentuk persepsi masyarakat saat ini. Media massa telah berulang kali menggambarkan kekejaman tentara Jepang sehingga menghasilkan sentiment buruk mengenai Jepang. Pendidikan patriotik oleh China berhasil meningkatkan nasionalisme. Kesimpulan periode tahun 1992 sampai 2002 bisa dikatakan berhasil mendorong pertukaran ekonomi karena percepatan reformasi China walaupun permasalahan serius muncul di bidang sejarah dan keamanan. Aksi revisionisme sejarah di Jepang bersamaan dengan penguatan pendidikan patriotik oleh pemimpin baru di China.

Periode tahun terakhir yaitu antara tahun 2002-2016, lonjakan terjadi atas hasil pembangunan ekonomi China mampu mengangkat posisinya di mata Internasional. Sisi lain dalam sisi sosial domestik China sendiri adanya upaya oleh administrasi Hu Jintao untuk menciptakan "Harmonious Society" (Chan, 2009). Selama masa jabatan 5 tahun pertama Hu Jintao tumpang tindih dengan kabinet Koizumi Junichiro di Jepang. Koizumi mendorong liberalisasi ekonomi dan berhasil mempertahankan hubungan yang kuat dengan AS, tetapi kunjungannya yang berulang-ulang ke Kuil Yasukuni mengganggu hubungan politik Jepang dengan China. Pada 2012, Xi Jinping dan Abe Shinzo muncul sebagai pemimpin politik paling berpengaruh di China dan Jepang. Melihat pada persepsi dan emosi publik di kedua negara, emosi Jepang terhadap China merosot tajam pada tahun 2004 setelah aksi sentimen anti-Jepang yang kuat oleh penonton di pertandingan sepak bola Piala Asia yang diadakan di China. Emosi terhadap Tiongkok merosot lagi pada 2005 ketika demonstrasi anti Jepang terjadi di sejumlah kota di China pada musim semi. Penurunan tajam persepsi publik terulang pada 2010 dan 2012 ketika demonstrasi anti-Jepang yang kejam menyusul insiden tabrakan Senkaku (Diaoyu) dan pembelian Kepulauan Senkaku oleh pemerintah Jepang dari badan privat.

Di sisi lain, orang China kesal dengan kunjungan tahunan rutin ke Kuil Yasukuni oleh Koizumi Junichiro setelah menjadi Perdana Menteri pada tahun 2001. Segera setelah kunjungan pertamanya ke Kuil Yasukuni, pada Oktober 2001 Koizumi juga mengunjungi Anti Japanese War Memorial Museum di pinggiran kota Beijing dan menyatakan permintaan maaf dan penyesalannya untuk perang. Meskipun ia mengeluarkan pernyataan yang terperinci tentang efek perang pada peringatan 60 tahun berakhirnya Perang Dunia II pada 2005, para pemimpin China merasa dikhianati karena mereka mengharapkan Koizumi untuk mengikuti prioritas Perdana Menteri Nakasone dan Hashimoto yang menahan diri untuk tidak pergi ke Kuil Yasukuni untuk kedua kalinya. Abe Shinzo menggantikan Perdana Menteri Koizumi pada tahun 2006 dan melakukan kunjungan resmi luar negeri pertamanya ke Beijing sebagai Perdana Menteri Jepang. Kedua belah pihak terus terang bertukar pandangan mengenai kegiatan kunjungan ke Kuil Yasukuni. Kemudian dinyatakan dalam Joint Press Statement yang dikeluarkan segera setelah pertemuan puncak bahwa Tokyo dan Beijing akan berusaha untuk membangun hubungan yang saling menguntungkan berdasarkan kepentingan strategis bersama.

Kesimpulannya dalam periode tahun 2002-2016 interaksi antara diplomasi dan politik dalam negeri tampak lebih menonjol daripada sebelumnya. Faktanya Koizumi Junichiro tidak pernah berkunjung ke Kuil Yasukuni sebelum menjadi Perdana Menteri. Motif awal Koizumi 
berusaha untuk mencari suara demi memenangkan pemilihan presiden LDP. Namun perlahan Koizumi mulai melihat masalah ini sebagai tarik ulur diplomatik dengan China, ketika para pemimpin China akhirnya menolak untuk bertemu Koizumi bahkan dalam kunjungan ke negara dunia ketiga. Perdana Menteri pada periode selanjutnya yaitu Abe Shinzo sebagai aktor penting dalam ideologi sayap kanan Jepang memperbaiki dan mengangkat hubungan bilateral dengan China setelah dilantik ke level lebih tinggi tidak hanya sekedar partner mutual strategis. Faktanya, opini publik Jepang pada saat itu semakin kritis mengenai diplomasi Koizumi terhadap China. Pada saat yang sama, ketidakpuasan sosial mengenai kondisi yang terjadi memunculkan peningkatan dalam reformasi kritis sayap kiri. Kesimpulannya dalam periode ini ada perubahan cepat dalam balance of power dalam kawasan sebagai bentuk kekuatan ekonomi dan militer China yang meningkat. Tinjauan dalam bab ini menunjukkan 44 tahun hubungan diplomatik antara Jepang dan China mengarah bahwa ada perbedaan kualitatif dalam hubungan dalam 20 tahun pertama dan 24 tahun terakhir. Secara keseluruhan, ada ketahanan dan kerapuhan dalam hubungan Jepang China. Ketahanan hubungan didasarkan pada kerja sama ekonomi, ikatan budaya dan sosial. Sedangkan kerapuhan hubungan bertumpu pada keamanan, wilayah, masalah sejarah, dan kesenjangan persepsi yang semakin lebar antara kedua negara. Perselisihan antara nasionalisme China dan Jepang berpusat pada tiga kelompok masalah yaitu pertama, masalah sejarah termasuk misalnya pembantaian Nanjing, Comfort Women, kunjungan ke Kuil Yasukuni, buku teks sejarah, dan senjata kimia. Masalah lain adalah upaya Tokyo untuk merevisi Aliansi ASJepang (Peng Er, 2017).

\section{Revisionisme Jepang}

Sejak 2012 Perdana Menteri Jepang Shinzo Abe telah berupaya membuat ulang kembali kebijakan luar negeri dan pertahanan Jepang. Agenda yang dibawah oleh Abe disebut sebagai 'Abe Doctrine' menuai banyak perdebatan. Tujuan Abe Doktrin adalah untuk memastikan bahwa Jepang dapat memainkan peran internasional yang lebih aktif dan lebih efektif mempertahankan kepentingan nasionalnya. Logika yang mendasari resep kebijakan doktrin, yang terkait dengan ide-ide kebijakannya, menunjuk ke arah Jepang yang memposisikan dirinya dalam cara yang lebih terfokus untuk menghadapi tantangan strategis langsung. Berupa tantangan seperti permasalahan oleh kebangkitan China, program nuklir dan rudal Korea Utara, dan komitmen Amerika yang terkadang ambivalen terhadap wilayah tersebut. Perlu diketahui bahwa dalam sejarah kebijakan luar negeri Jepang sangat dipengaruhi dengan 'doktrin' seperti contohnya cukup terkenal Doktrin Yoshida, Fukuda Doktrin dan Koizumi Doktrin. Posisi doktrin dalam kebijakan luar negeri Jepang sering digunakan sebagai tambahan terhadap kebijakan. Menurut Holsti, doktrin kebijakan luar negeri sebagai seperangkat keyakinan eksplisit yang dimaksudkan untuk menjelaskan realitas dan biasanya menentukan tujuan untuk tindakan politik. Berbagai pendapat ahli menyatakan doktrin kebijakan luar negeri berhubungan langsung dengan peran kepala negara dalam sistem internasional terutama dalam perhitungan peta jalan bagi pembuat kebijakan menentukan pertimbangan tujuan akhir. Dengan demikian, doktrin dapat dipahami sebagai menggabungkan dua elemen dasar yaitu gagasan kebijakan yang terdiri dari keyakinan, prinsip, dan harapan dunia pembuat kebijakan; dan resep kebijakan yang lebih konkret.

Perlu ditekankan dalam rujukan sumber menyimpulkan adanya sedikit konsistensi antara antara gagasan kebijakan nasionalis Abe Doctrine dan resep kebijakannya. Ciri karakter Doktrin Abe bisa dikatakan sebagai revisionis dan nasionalis yang sedang mengarah pada jalan radikal. Abe condong berfokus pada narasi sejarah perang Jepang mengenai pandangan prestise sebagai 'negara normal' (futsu no kuni). Retorika Abe terlihat sangat mengikuti tokoh politik sayap kanan lainnya di Jepang, seperti Nakasone Yasuhiro, yang berpendapat bahwa 
Jepang perlu menyelesaikan semua akun tentang masalah-masalah politik pasca perang. Upaya pemerintah Jepang dalam mempengaruhi domestik demi kepentingan nasional terlihat pada upaya penanaman rasa patriotisme dan nasionalisme kepada masyarakat Jepang secara luas. Kebangkitan Nasionalisme ini pertama kali terlihat dalam pemerintahan pertama Abe (2006-07) dan tren serupa dapat diidentifikasi di periode kedua Abe menjabat sebagai perdana Menteri. Harapan utama Doktrin Abe adalah bahwa kekuasaan dan keamanan hanya dapat dicapai melalui otonomi yang lebih besar, dimana hanya dapat diperoleh jika Jepang menetapkan sejarah baru tentang masa lalu kekaisarannya dan merekayasa ulang institusi keamanannya. Ambisi Abe untuk mengakhiri rezim pasca perang (sengo taisei kara dakekyaku) yang diarahkan untuk memulihkan otonomi melalui perubahan konstitusi. Seperti yang dikemukakan Abe "revisi konstitusi adalah simbol dari pemulihan kemerdekaan" (dokuritsu no kaifuku). Ciri kebijakan luar negeri ini adalah revisionis dan nasionalis dengan cita cita mewujudkan Jepang sebagai negara 'normal' dan 'indah' dengan cara tidak perlu meminta maaf atas sejarah perang. Misi Abe untuk membawa Jepang lebih aktif di Internasional dengan mengakhiri rezim pasca perang (sengo taisei kara dakkeyaku) untuk mencapai otonomi besar melalui pencapaian kekuasaan dan keamanan nasional lewat kebangkitan nasionalisme.

\section{Konsensus Sejarah}

Kepercayaan ini diartikan sebagai kepercayaan yang dianut masyarakat Homogen tertentu terkait konsensus sejarah (Shared Belief of Homogenous Communities). Kepercayaan konsensus sejarah yang mereka anut cenderung berbeda dengan konsensus masyarakat Heterogen yang tidak dalam tekanan atau rezim. Nilai yang mereka anut cenderung tidak terbukti secara ilmiah dan bertentangan dengan narasi historiografi yang benar. Revisionisme Jepang di China merebak ketika jaringan Hotel APA milik Toshio Motoya, tidak keberatan menolak atas kekejaman militer Jepang pada Perang Dunia. Argumennya mengenai kebohongan pembantaian Nanjing dengan secara gamblang dipajang di ruang tamu seluruh cabang hotelnya. Korea dan China mengajukan protes dan boikot dengan memutus hubungan kerjasama dengan APA saat Asian Winter Games. Menarik kasus tersebut sikap revisionisme yang dilakukan di kalangan pebisnis adalah praktik keberhasilan dari taktik penyebaran revisionisme dari Perdana Menteri Shinzo Abe.

Di tahun ke-5 nya berkuasa Abe tidak merahasiakan pandangan nasionalismenya. Abe mengatakan Jepang harus menyingkirkan hambatan sejarah masa lalu, termasuk mengubah konstitusi yang menolak perang yang diberlakukan oleh penjajah Amerika Serikat setelah Perang Dunia II. Jeff Kings, Direktur Studi Asia di Temple University Jepang mengatakan ide Revisionis Jepang adalah berusaha untuk menulis ulang sejarah perang Jepang di Asia dan mempromosikan narasi pembebasan yang mengabaikan kejahatan perang yang terjadi (AFP, 2017). Melihat struktur masyarakat Jepang yang sering diibaratkan sebagai masyarakat Homogen yang unik dan seragam. Argumen ini berdasar pada pencarian basis data akademik untuk publikasi dalam Studi Jepang. Konsep homogen tersebut mengkristal menjadi pseudosains yang disebut Nihonjinron. Dimensi politik dalam Homogenisme Nihonjinron terletak pada mempertahankan status quo (Debito Arudou, 2010). Kondisi masyarakat Jepang saat ini condong memiliki ketertarikan baru dalam melindungi identitas budaya sehingga beberapa kelompok nasionalis dan revisionis kehilangan popularitas dan kekuatan politiknya. Taktik penolakan Pembantaian Nanjing cukup wajar dilakukan oleh lingkaran revisionis ini, termasuk partai Demokrat Liberal yang berkuasa saat ini. Sebagai contoh, dewan LDP mengadakan review legislator pada tahun 2007 membahas jumlah korban jiwa dan menyimpulkan bahwa jumlah nya normal untuk peperangan. Nariaki Nakayama mengatakan jumlah kematian terbanyak seharusnya 20.000 jiwa. 
Untuk memperkuat pendirian politik mereka, anggota LDP dan Nippon Kaigi sering melakukan ritual yang dipublikasikan besar besaran untuk mengunjungi Kuil Yasukuni di Tokyo. Kuil beraliran Shinto ini menyimpan sisa peninggalan 1068 penjahat perang, 14 di antaranya dihukum karena kejahatan perang kelas A dan merupakan tempat peristirahatan terakhir bagi Jenderal Iwani Matsui. Bahkan kuil ini memberikan penjelasan mengenai Nanking Operation' bukan sebagai kejahatan perang tetapi sebagai komponen penting Jepang untuk misi "pembebasan" Asia Timur dan tidak menulis istilah 'pembantaian'. Respon publik Jepang terkait kunjungan politikus dan kalangan revisionis ke kuil Yasukuni menuai poling setuju dan faktanya kalangan lansia berpendapat Jepang tidak perlu meminta maaf atas kejahatan perang. Generasi umur 65 tahun keatas merupakan pemegang demografi politik terkuat di Jepang karena 68\% dari mereka menjabat sebagai Dewan Perwakilan Rakyat. Hal ini berpengaruh dalam haluan Jepang menuju sayap kanan terlihat dari pengaruh generasi tua di pemilihan nasional dan wakil daerah (Massachusetts Institute of Technology, 2018). Proses penyebaran kepercayaan yang Homogen dilakukan pemerintah Jepang melalui ranah pendidikan. Revisi The Fundamental Law of Education (FLE, kaisei kyoiku kihonho) pada tahun 2006 ,diajukan oleh partai sayap kanan LDP bersama Abe merubah isi undang-undang menjadi lebih nasionalis dan patriotis ("MEXT : Basic Act on Education," 2021). Anggapan nilai-nilai nasionalistik, yang melekat pada pendidikan sebelum perang merupakan tindakan berbahaya dan tidak demokratis. Maka FLE bertujuan untuk mendemokratisasikan prinsipprinsip pendidikan untuk membangun masyarakat yang demokratis, cinta damai, beradab dan sebagai masyarakat Internasional.

Faktanya, keseluruhan dokumen setelah direvisi menggunakan frasa yang melemahkan tujuan dan nilai-nilai yang ada dalam hukum asli. Hasil perubahan ini melemahkan posisi konstitusi dan semangat individual yang telah ditulis oleh Amerika. Sebaliknya, pasca revisi Undang Undang memprioritaskan semangat publik dan tugas publik termasuk pembelaan terhadap negara daripada memperjuangkan kepentingan individu. Undang-undang ini menggunakan bahasa anakronistik yang identik dengan gaya kepenulisan saat masa perang tentang pendidikan. Dengan demikian revisi undang-undang FLE 2006 ini lebih mengarah pada manifesto ideologis dibanding produk dokumen hukum. Abe Shinzo menekankan banyak frasa pada revisi Undang-undang ini terutama pada kata 'moral' sebagai bagian utama. Abe terus melanjutkan reformasi pendidikannya tak lama setelah ia terpilih untuk masa jabatan kedua pada tahun 2012. Untuk mempercepat tujuan pembangunan kembali pendidikan, Abe membentuk The Council for the Implementation of Education Rebuilding (Kyoiku saisei kaigi / Kyoiku saisei jikkeo kaigi) dan menunjuk Shimomura Hakubun sebagai menteri pendidikan. Pentingnya pembentukan dewan ini terletak pada kenyataan bahwa ia membentuk struktur paralel yang melewati Kementerian Komite Sentral Pendidikan MEXT. Bersamaan juga dengan rencana Shimomura untuk merevisi buku teks sekolah dari SD sampai SMA untuk menerapkan FLE yang telah direvisi termasuk promosi patriotisme.

Ideologi gerakan revisi buku teks sejarah dengan demikian dalam banyak hal dapat disimpulkan sebagai reproduksi kesadaran masyarakat tertutup yang homogen (sakoku ishiki) dari sistem kekaisaran modern. Gerakan Revisionis dan narasi yang disebarkan adalah serangkaian kata-kata hampa yang dimaksudkan untuk konsumsi masyarakat Jepang, diciptakan untuk menyembuhkan jiwa nasional Jepang yang terluka (Kolmas, 2018). Kepercayaan bersama dalam masyarakat Homogen yang tertutup oleh Masyarakat Jepang terhadap Pembantaian Nanjing berakar pada aktor Revisionis yaitu Shinzo Abe bersama dengan partai sayap kanan LDP. Justifikasi kepercayaan revisionis ini berhasil menyentuh masyarakat dari berbagai lapisan masyarakat tergambarkan dalam rasa bangga dan tidak malu mengenai Jepang di masa lalu. 


\section{Heterogenitas dan Penolakan terhadap Sejarah}

Hal ini diartikan sebagai adanya perbedaan pendapat dari masyarakat Heterogen dalam konsensus sejarah (Dissent from Heterogenous Historiographic Consensus). Kelompok Heterogen ini diidentifikasi sebagai masyarakat yang tersebar dan luas biasanya kelompok identitas yang berbeda seperti negara atau bangsa. Mereka mendukung Revisionisme Sejarah sebagai pembaharuan pengetahuan murni bukan sebagai alat politik. Ketika sejarah dan memori pembantain Nanjing menjadi internasional, para revisionis Jepang telah berusaha meyakinkan dunia bahwa apa yang dikenal sebagai Pembantaian Nanjing telah dipalsukan. Semangat narasi revisionis ini memiliki banyak kesamaan dengan beberapa pernyataan dalam pola emosional, nasionalistis, dan etnosentris tentang Nanjing yang berasal dari pandangan China dan Amerika Serikat. Di China, banyak aktifitas dan pameran museum yang berhubungan dengan Nanjing telah menumbuhkan nasionalisme. Tujuannya untuk memperkuat kesetiaan kepada pemerintah dengan memberatkan pada pengulangan pada 300.000 kematian. Selain itu, beberapa karya Amerika di Nanjing telah menganggap kekejaman itu berasal dari dugaan karakter rasial Jepang atau perilaku budaya yang unik, mengabaikan pemikiran rasis yang dimiliki bersama yang berada dibalik kebiadaban perang ("The Nanjing Massacre. Changing Contours of History and Memory in Japan, China, and the U.S.," 2021).

Pada tahun 2015, Revisionisme Jepang menjadi permasalahan di antara hubungan bilateral Jepang dengan Amerika Serikat. Kementerian luar negeri Jepang meminta McGrawHill (perusahaan besar penerbit buku edukasi di Amerika) untuk menghapus sebuah bagian yang berisi referensi untuk comfort women dari sebuah teks tentang sejarah dunia yang digunakan oleh sekolah-sekolah menengah di California. Bagian ini mengatakan bahwa tentara kekaisaran Jepang melakukan tindakan paksaan merekrut, wajib militer dan menarik sebanyak 200.000 wanita berusia 14 hingga 20 tahun untuk melayani di rumah bordil militer. Ini adalah bentuk tekanan pertama kalinya dalam sejarah kepada para penerbit di AS. Reaksi McGraw-Hill terhadap para pejabat Konsulat Jepang saat pertemuan di New York adalah negatif dan tetap menolak merubah bagian tersebut dengan argumen sesuai dengan fakta sejarah. Sejauh ini aktifitas penyensoran buku teks sejarah hanya dilakukan dalam Jepang, sehingga membuat jurang besar pengetahuan sejarah anak-anak mengenai kebenaran perang. Hanya anak anak masyarakat Jepang yang buta akan agresi Jepang karena upaya Revisionisme pemerintah Jepang (McCurry, 2015).

Pada tahun 2015 Jepang membuat keputusan kontroversial yaitu menarik pendanaan lebih dari $f, 34$ juta untuk The United Nations Educational, Scientific and Cultural Organization (UNESCO) menyusul protes terhadap daftar dokumen yang terkait dengan pembantaian Nanjing. Jepang sebagai salah satu penyumbang dana terbesar untuk UNESCO melakukan penarikan dana setelah UN Cultural and Scientific Body menyetujui permintaan Beijing untuk mendaftarkan dokumen pembantaian massal dan pemerkosaan Nanjing 1937. Dokumendokumen itu tertulis dalam daftar program Memory of the World. Jepang telah menyerukan agar dokumen Nanjing tidak dimasukkan dan menuduh UNESCO telah dipolitisasi (Guardian, 2016). Adanya konsensus berbeda dianut oleh kelompok Heterogen seperti China, Amerika dan UNESCO menunjukkan garis pembatas realita dan fakta Pembantaian Nanjing dengan konsensus Homogen Jepang. Dalam analisis ini pihak heterogen tidak mengalami paksaan atau dibawah tekanan suatu rezim tunggal. Upaya Jepang dalam meyakinkan komunitas internasional terhadap aksi Revisionisnya terlihat dengan statement penolakan dari Kementerian Luar Negeri mengenai Sejarah Nanjing yang sebenarnya. Perbedaan pendapat mengenai fakta pembantaian Nanjing antara Jepang melawan China, Amerika dan UNESCO memperlihatkan upaya pengaburan fakta sejarah secara internasional. 
Penolakan sejarah dimaknai sebagai penolakan atas rasa bersalah mengenai kejadian sejarah (The Denial Historical Guilt). Penolakan ini merupakan bagian dari nilai 'therapeutic value' untuk memberikan nilai terapis terhadap pelaku kejahatan. Proses ini juga termasuk pengabaian bukti sejarah ilmiah. Pasca Perang Dunia ke-2 Jepang menerima Deklarasi Potsdam dan menyerah pada Agustus 1945, secara resmi mengakui perang agresi dan pembantaian Nanjing yang dilakukan oleh tentara Jepang. Deklarasi Potsdam mengecam agresi Jepang dan menetapkan hukuman bagi penjahat perang. Setelah penyerahan itu, International Military Tribunal for the Far East (IMFTE) berlangsung di Tokyo. Pada November 1948 pengadilan menjatuhkan putusannya bahwa bentuk kejahatannya adalah agresi perang yang menjadi tanggung jawab Jepang dan pengadilan itu juga mengakui bahwa 200.000 orang telah dibantai di Nanjing. Kemudian, dalam pasal 11 San Francisco Peace Treaty tahun 1951, Jepang mengisyaratkan penerimaan putusan pengadilan kejahatan perang tentang perang agresi dan pembantaian Nanjing. Tetapi pada kenyataannya hasil pengadilan ini diabaikan begitu saja ketika perjanjian mulai diberlakukan.

Penolakan terhadap pembantaian Nanjing berpusat pada pada pertanyaan tentang jumlah angka korban. Pada awalnya, para penjahat perang telah menyebut pembantaian itu sebagai "ilusi" atau fiksi, tetapi pandangan ini dibantah dengan bukti saintifik hasil dari kemajuan dalam penelitian ilmiah. Sehingga ranah mereka mengecil dan terpaksa berdebat tentang jumlah korban, jika dampak pembantaian Nanjing jumlahnya kecil itu tidak bisa dikategorikan sebagai pembantaian. Debat ini membatasi kerangka waktu dan tingkat geografis peristiwa untuk menghitung jumlah korban sesedikit mungkin ("Refuting Denial," 2013). Pasca Perang Dunia Kedua berakhir blok Axis yaitu Jerman, Jepang dan Italia diadili atas kejahatan perangnya oleh pihak sekutu. Upaya peradilan ini tentunya menghasilkan sebuah rasa bersalah dan tanggung jawab atas kesalahan yang pernah mereka lakukan. Rasa bersalah dan malu mengenang kejahatan di masa lalu dirasakan oleh Jerman dan Italia tapi tidak dengan Jepang. Perlakuan terhadap pemimpin blok Axis umumnya mengambil dua jalur yang berbeda. Pada satu sisi Jerman secara sistematis melakukan "de-Nazifikasi" atas paksaan Sekutu selama bertahun-tahun. Sedangkan perlakuan terhadap penjahat perang Jepang dilakukan secara serampangan oleh Amerika. Pengadilan kejahatan perang dengan cepat disimpulkan atau dipotong dan banyak militeris yang memegang jabatan tinggi selama tahuntahun perang diizinkan kembali ke jabatan politik. Penjahat perang kelas A paling terkenal yang lolos dari hukuman adalah kakek dari Perdana Menteri Abe Shinzo yaitu Kishi Nobusuke. Kishi pernah menjabat sebagai perdana menteri 2 periode dan banyak politikus masih memiliki relasi sebagai penjahat perang menguasai parlemen dengan ideologi ultra konservatif sayap kanan.

Argumen yang mendasari gagalnya terbentuk rasa bersalah Jepang terhadap pembantaian Nanjing adalah kegagalan Amerika menghukum para penjahat perang yang kini tetap hidup dan menguasai perpolitikan Jepang. Hasilnya banyak orang masih menolak dengan keras kepala Jepang pernah terlibat dalam kejahatan perang. Penolakan ini juga diperparah dengan alibi menyalahkan Amerika karena menjatuhkan bom atom dan melihat peristiwa ini sebagai tindakan kriminal yang perlu balas dendam ("Nanking Massacre Denial - How the Far Right in Japan Kept Power - The Casemate UK Blog," 2017). 


\section{Konstruksi Imaji dan Harga Diri}

Merupakan sebuah tindakan dalam mempromosikan diri untuk meningkatkan kesadaran publik bahwasannya mereka sejatinya terhormat dan bangga. Promosi ini melibatkan publikasi suatu produk organisasi dimana semuanya mencakup aksi mendukung peningkatan harga diri. Buku yang kerap muncul di toko buku di Jepang ini dikarang oleh Fujioka Nobukatsu dan Liberal Historiograpby Study Group adalah kritik yang ditujukan kepada sistem pemeriksaan Kementerian Pendidikan untuk buku teks. Pendidikan sejarah menurut Fujioka harus menguntungkan Jepang dan membuat orang Jepang bangga terhadap bangsanya lagi berdasar pada pandangan masyarakat melihat buku sejarah sebagai media 'masokis'. Buku Kyokasho $\mathrm{Ga}$ Oshienai Rekishi memfokuskan narasi viktimisasi dan melodrama seperti halnya sama dengan evaluasi fakta sejarah. Sebagai manifestasi dari narasi viktimisasi, para revisionis buku teks mengandalkan persepsi Jepang yang luas tentang korban. Sementara Amerika Serikat masih digambarkan sebagai penjajah. Revisionis membuat argumen seperti, "Mengapa kita harus mengajarkan pandangan sejarah yang dimiliki orang China?" narasi ini mengisyaratkan edukasi sejarah akan membuat Jepang "lemah,", berimbas pada penghinaan bangsa di depan China.

Jepang terlepas dari perannya sebagai negara adidaya dalam ekonomi, tidak mendapat penghargaan di arena politik internasional dan karenanya tidak memiliki identitas di antara negara-negara lain. Rasa malu karena menjadi orang Jepang, dan terutama ketidakmampuan untuk bangga pada diri sendiri di hadapan orang lain, sering dikutip dalam tulisan-tulisan kelompok Fujioka dan merupakan alasan mereka berpikir orang Jepang memperburuk keadaan dengan berulang kali mengutuk diri mereka sendiri. Cara berpikir ini cukup populer di sebarkan di media populer, bioskop, televisi, dan sastra. Narasi habamono (cerita kasih sayang ibu) atau mitos penderitaan di Hiroshima dan Nagasaki mengungkapkan tidak pernah diizinkan untuk merasakan nasionalisme. Banyak ketakutan tentang kelemahan Jepang diarahkan pada elemen-elemen di dalam negeri yang dianggap merusak perasaan Jepang tentang diri mereka sebagai bangsa yang seragam dan homogen.

Pelaku Revisionis buku teks sejarah bereaksi terhadap ancaman-ancaman ini melalui perangkat ideologis sejarah dan pendidikan. Fujioka dan para pengikutnya menjadikan sejarah sebagai senjata konfrontasi, atau bahkan sarana untuk membangun orang Jepang yang bangga yang dapat memenangkan perang yang mereka bayangkan sudah dekat. Untuk membangun kembali badan nasional Jepang dan menciptakan "nasionalisme yang sehat" (kenzenna nashonaruizumu - frase yang sering digunakan revisionis) tergambarkan kejahatan perang Nanjing termasuk comfort women harus dilupakan (Gerow, 1998). Usaha untuk menanamkan patriotisme dan rasa kebangsaan telah dilakukan sejak lama dari tahun 1970an. Pemerintah Jepang menerapkan standar kurikulum yang direvisi (gakushū shidō yōryō) di sekolah dasar, menengah pertama, dan atas. Pemerintah mengharuskan sekolah siswanya menyanyikan lagu kebangsaan dan mengibarkan bendera nasional pada acara-acara khusus. Dalam pendidikan sejarah, para guru diminta untuk mengajarkan mitos yang menyatakan asal mula ilahi bangsa Jepang, seperti yang diceritakan dalam Records of Ancient Matters (Kojiki) dan Chronicles of Japan (Nihon shoki). Pada tahun 1979 pemerintah juga membangkitkan kembali sistem kalender (gengō) yang telah digunakan sebelum kekalahan negara Jepang. Pada akhir 1970-an, adanya keretakan signifikan melebar di antara pemerintah mencoba mengikis memori Perang Asia-Pasifik dan kekuatan progresif yang mencoba melestarikannya. Semenjak tahun 1982 adanya tren peningkatan penulisan buku sejarah berintrik revisionisme di masyarakat sebagai contoh, jurnalis Kitsukawa Manabu, menerbitkan bukunya 'Japan Was Not a Aggressive Nation' (Nibon wa shinryaku koku de wa nai) pada tahun 1983 untuk mengajari orang-orang sebangsanya tentang "sejarah sejati" Jepang ("Historiography of the Asia-Pacific War in Japan | Sciences Po Mass Violence and Resistance - Research Network," 2008). 


\section{Membuang Keterasingan}

Merupakan usaha eliminasi atau menghilangkan rasa terasingkan dan absurditas dalam komunitas. Dalam konsep ini penyebaran teori konspirasi dan mitos secara nasional adalah poin utama untuk merangkul sisi logika dan psikologis suatu masyarakat. Cerita fiksi disesuaikan dengan norma dan nilai sehingga komunitas homogen dapat menerima logika tersebut. Revisionisme Jepang bahkan bisa dikatakan selangkah lebih maju dari Revisionisme Auschwitz, Jerman. Dalam waktu kurang dari dua dekade sejak tanggal kekalahan Jerman, kaum revisionis mulai menulis rekonstruksi fakta dan peristiwa mereka. Artinya, Auschwitz tidak ada dan tidak ada pembantaian orang Yahudi. Sedangkan di sisi lain Jepang berpendapat bahwa serangan terhadap Pearl Harbor, dan invasi ke China dan bagian lain di Asia bukanlah tindakan agresi. Tindakan tersebut adalah manuver defensif melawan imperialisme Barat. Banyak korban agresi Jepang tetap diam tentang penderitaan mereka. Aktor Revisionisme historis mengatakan bahwa kesunyian para korban membuktikan kekejaman tidak pernah terjadi. Asumsi dasar aktor revisionis terletak pada keyakinan kuat kepada Nasionalisme. Nasionalisme menurut mereka tidak dapat dirumuskan tanpa egoisme nasional atau kepentingan nasional. Sebagai contoh menganggap invasi Jepang ke Korea sebagai hasil dari nasionalisme Jepang (National Egoism \& National Interest). Selama itu adalah tindakan pertahanan nasional, perang invasi dengan demikian dapat dibenarkan.

Pendapat bahwa kemenangan Jepang atas imperialisme Barat dalam setiap konfrontasi dengan Barat mengangkat alasan nasionalistis Jepang ke nilai dunia universal berimbas pada gerakan kemerdekaan nasional pasca perang di banyak negara Asia dan Afrika. Ide mereka terhadap membebaskan tidak hanya Jepang tetapi juga seluruh Asia dari dominasi Barat adalah dasar hilangnya perasaan alienasi. Ide tersebut mendasari anggapan nasionalisme Jepang sebagai ideologi fundamental gerakan kemerdekaan negara lain adalah pembelaan terhadap gagasan Aliansi Asia Timur [tôa renmei ron]. Nasionalisme Jepang atau bisa disebut sebagai tôa renmei ron adalah ideologi elit untuk supremasi rasial Jepang dan termasuk chauvinisme pria Jepang. Hal ini juga mempengaruhi aktor Revisionis untuk mulai berbicara mengenai merevisi konstitusi perdamaian. Tujuan mereka adalah mengubah konstitusi menjadi konstitusi "normal" yang dimana memungkinkan kehadiran kekuatan militer di Jepang. Alasan mendasar dari tujuan ini adalah untuk hidup damai bersama dengan tetangga Asia [heiwa tekina kyôsei no tame], istilah rukun tetangga dengan Asia ini muncul selama Perang Dunia Kedua. Secara harfiah arti kata 'kyôsei' dari 'beiwa tekina kyôsei no tame' berarti hidup bersama dari tuan dan budak. Maka analogi dari Kyosei ini bisa dianggap relevan dalam perbudakan dan wajar memukuli budak walaupun hidup bersama (Oh \& IshizawaGrbić, 2000).

Mitos yang dianut masyarakat Jepang mengenai persepsi pemerintahan mereka yang murni dan suci tergambarkan melalui istilah 'Kami no Kuni'. Penerjemahan sebagai Negara Tuhan yang sakral tergambar dalam praktik ideologi menanggapi tantangan kolonialisme barat dalam masa perang dunia. Pada 15 Mei 2000, Perdana Menteri Mori Yoshiro menggunakan istilah ini pada pidato di depan anggota Diet. Pernyataan ini mengembalikan kembali ingatan mengenai ideologi masa perang yang berpusat Kaisar sebagai dewa dan pusat pemerintahan. Istilah ini juga merujuk pada ide Jepang adalah Negara Tuhan yang superior diatas negara lain (Antoni, 2003). Istilah 'Kami no Kuni' mengacu pada sistem kekaisaran yaitu 'Tenno' dimana memusatkan kaisar sebagai dewa dan simbol Jepang. Dukungan kaisar Jepang dalam gerakan revisionisme dilihat pada tahun baru 2015, Kaisar Akihito dalam pesan tahun baru mendesak warga Jepang untuk belajar dari sejarah menyangkut peringatan ke-70 Perang Dunia Kedua berakhir (Kingston, 2016). Aksi ini tentunya cukup mengejutkan karena seharusnya Kaisar tidak memperlihatkan keberpihakan dalam politik. Pidato ini memicu 
semangat Nasionalisme Shinzo Abe untuk mengglorifikasikan Jepang sebagai 'Kami no Kuni' dari masa perang ke era ini.

Justifikasi atas nilai nilai mitos demi menghilangkan rasa terasingkan tercermin dalam bagaimana masyarakat Jepang digerakkan dengan Nasionalisme semu melalui 'beiwa tekina kyôsei no tame' dan 'Kami no Kuni'. Mitos ini berada pada bagaimana Jepang memposisikan diri mereka terhadap negara tetangga di Asia dari ancaman westernisasi. Maka logika yang terbentuk rasa wajar dan legal melihat kejahatan perang sebagai bentuk perlindungan bukan kriminal. Eliminasi rasa alienasi menggantikan title Jepang dari 'Penjahat Perang' menjadi 'Pelindung Asia' melalui mitos dan nilai Jepang. Masyarakat Homogen Jepang yang menganut konsensus sejarah bahwasannya Jepang tidak perlu meminta maaf dan bertanggungjawab atas pembantaian Nanjing berbeda dengan konsensus masyarakat Heterogen Global dari China, Amerika dan UNESCO. Perbedaan pengakuan tentang Pembantaian Nanjing menciptakan perbedaan pendapat besar sehingga mengaburkan kebenaran tunggal Nanjing. Upaya Revisionis Jepang ini lebih berfokus kepada domestik dibanding internasional untuk meraih Nasionalisme dan Patriotisme kembali seperti saat perang dunia. Penolakan rasa bersalah terjadi saat Amerika gagal menghukum Jepang sebagai penjahat perang sehingga menimbulkan upaya promosi penghargaan diri lewat penyebaran buku sejarah revisionis. Semua upaya ini dijustifikasi Jepang dengan menghilangkan rasa alienasi dan keabsurdan lewat mitos tua Jepang mengenai kemurnian, negara ilahi dan superior yang berhak berkuasa atas negara lain.

Implikasi peristiwa pembantaian Nanjing yang terjadi 89 tahun lalu masih memiliki posisi penting dalam citra Jepang dalam abad ini. Sejarah dalam proses pembentukan identitas bangsa adalah elemen strategis untuk menyusun strategi kebijakan suatu Negara. Terlepas dari pencapaian besar Jepang menjadi raksasa ekonomi terbesar di Asia tidak luput dalam kenangan rezim Perang Pasifik. Tetapi dilema dalam perbaikan citra ini mengorbankan harga diri tinggi dari sebuah bangsa, seperti pengakuan tindakan kriminal dan berhak dijustifikasi sebagai bangsa yang gagal. Jalan panjang Jepang dalam rezim pasca perang pasifik perlahan mengikis inti dari identitas bangsa mereka. Nasionalisme dan Patriotisme disimbolkan sebagai tentara kekaisaran yang bengis sehingga illegal untuk disuarakan. Menyerahkan setengah kedaulatan kepada sekutu membuat Jepang berada dibawah titik 'tidak berdaya'. Pusaran rasa tidak berdaya dan haus akan kehormatan membuat strategi Revisionisme Sejarah melawan Pembantaian Nanjing menjadi titik balik Jepang menemukan identitas yang sempat menghilang.

Melalui Pembantaian Nanjing, sebuah simbol ketakutan dan trauma masyarakat Jepang luas menjelma sebagai objek yang bisa ditolak keberadaanya. Upaya penolakan dengan memelintir kebenaran tunggal empiris bisa dikonotasi upaya putus asa Jepang menyangkal stigma buruk sebagai agresor perang yang keji. Perlawanan ini tercermin melalui perselisihan Jepang terhadap konsensus global yang telah terbukti. Walaupun tidak bisa benar-benar menghapus, Revisionisme bisa membuat kebenaran itu kabur atau dipertanyakan adalah cukup mengobati rasa sakit. Tetapi tidak semua bagian dari masyarakat Jepang benar benar menaruh perhatian terhadap isu Revisionisme Sejarah kepada Pembantaian Nanjing. Terutama pada anak-anak muda yang tidak terlahir pada era Perang Dingin. Masyarakat Jepang kini tidak lagi sepenuhnya percaya dengan keilahian nya atau mitos dewa mereka, masuknya nilai barat melalui globalisasi menjadi salah satu faktor kenapa identitas Jepang tergerus selain pelucutan kedaulatan dari sekutu.

Pada akhirnya penulis berasumsi Revisionisme Jepang adalah agenda yang diusung oleh kalangan sayap kanan yang hingga kini berusaha merubah konsensus sejarah di level Nasional. Keberhasilan dari strategi ini diharapkan seluruh masyarakat Jepang dapat menemukan kehormatan dan identitas Jepang sebagai negara yang benar benar merdeka dan 
berhak merasakan Nasionalisme kembali. Citra buruk sebagai negara yang jahat dan minta maaf berulang kali kepada negara lain yang telah merdeka dapat selesai dan Jepang memulai agenda baru- bebas dari rezim trauma perang pasifik.

\section{KESIMPULAN}

Sejarah dibentuk dan dimobilisasi untuk membenarkan proyek-proyek politik saat ini sampai pada membenarkan rezim atas nama keadilan. Bukti ini menjelaskan bahwa sejarah memegang komponen besar tetapi permasalahan timbul ketika sejarah dipolitisasi secara sengaja untuk menjustifikasi aksi moral. Tak ada nya penetapan dan pemahaman luas terhadap sebuah peristiwa sejarah internasional menimbulkan aksi manipulasi dokumen sejarah. Pertanyan dalam skripsi ini berputar pada apakah pilihan perspektif menimang Nanjing melalui narasi politik atau fakta sejarah. Latar belakang dimulai dari UNESCO yang mengesahkan Dokumen Pembantaian Nanjing ke Internasional mengadu persepsi antara Jepang dengan dunia Global.

Hubungan antara Jepang dan China yang merupakan pasang surut mengadu kebangkitan Nasionalisme di kedua belah pihak sehingga berujung pada lemparan kecaman. Kebangkitan sayap kanan Jepang yang menguasai parlemen saat ini didukung oleh Perdana Menteri Nasionalis Shinzo Abe menguatkan Agenda Jepang. Revisionisme Sejarah dilakukan Jepang dilatarbelakangi atas pembunuhan massal dan pemerkosaan di Nanjing China sehingga Jepang dikenal sebagai penjahat perang hingga saat ini. Persepsi ini menimbulkan proyeksi buruk citra Jepang sebagai negara besar di Asia Pasifik, sehingga demi merubah citra tersebut upaya Revisionisme Sejarah dilakukan demi menghilangkan tanggung jawab dan minta maaf atas pembantaian Nanjing. Mengakhiri rezim pasca perang dengan narasi 'normalisasi' Jepang yang baru dan aktif di mata global.

Maka strategi dalam melindungi Jepang dari narasi Pembantaian Nanjing dari Internasional melalui penekanan Aksi Revisionisme melalui Nasionalisme. Analisis studi ini ditelaah melalui Konsep oleh A. Tucker yang mengidentifikasi Shared Beliefs dan Therapentic $V$ alue. Masyarakat homogen mempercayai bahwasannya Jepang tidak perlu meminta maaf dan mengakui kejahatan perang berbanding terbalik dengan konsensus historiografis Heterogen yang mengakui secara empiris Pembantaian Nanjing terbukti dan benar adanya. Nilai terapis dari penolakan sejarah berasal dari kegagalan pemberian rasa jera dari sekutu Amerika. Promosi membanggakan diri sendiri dengan sebaran narasi viktimisasi dan melodrama dari buku sejarah yang dijual bebas didukung dengan revisi kurikulum sekolah. Eliminasi rasa asing melalui mengangkat nilai superioritas, murni dan Ilahi dalam nilai Toa Renmei Ron dan Kami no Kuni mampu menjadi bahan bakar utama strategi Revisi Sejarah terhadap Nanjing. Temuan menarik dalam tulisan ini strategi Revisionisme Sejarah tidak mampu menyentuh generasi muda dengan semangat pasifisme.

\section{DAFTAR PUSTAKA}

80 years later: can China, Japan overcome Nanking Massacre's legacy? (2017, 10

December). Retrieved 6 November, 2019, from https://www.scmp.com/weekasia/opinion/article/2123261/80-years-later-can-china-japan-overcome-nankingmassacres-legacy.

Afp. (2018, 31 October). Japan history revisionists bolder under Abe: analysts. Retrieved 11 February, 2020, from https://gulfnews.com/world/asia/japan-history-revisionistsbolder-under-abe-analysts-1.1980341

Antoni, K. J. (2003). Religion and national identity in the Japanese context. Münster: Lit. 
Arudou, D. (2010, 2 November). 'Homogeneous,' 'unique' myths stunt discourse. Retrieved 11 February, 2020, from https://www.japantimes.co.jp/community/2010/11/02/issues/homogeneousunique-myths-stunt-discourse/\#.XkKBo75MTDc

Asian History Commons. (2017, 19 May). Asian History Commons. Retrieved from https://scholarworks.uno.edu/td/2312/

Basic Act on Education (Act No. 120 of 22 December, 2006) . (n.d.). Retrieved 20 February, 2020, from https://www.mext.go.jp/en/policy/education/lawandplan/title01/detail01/1373798 htm

Butterworth G. (2007) Historical Revisionism in New Zealand: Always Winter and Never Christmas. In: Rata E., Openshaw R., Friedman J. (eds) Public Policy and Ethnicity. Palgrave Macmillan, London

casemate_uk. (2017, 1 February). Retrieved 23 February, 2020, from https://www.casematepublishing.co.uk/blog/2017/02/01/nanking-massacre-denialhow-the-far-right-in-japan-kept-power

Cattini, G. C. (2011). Historical revisionism. Transfer Journal of Contemporary Culture, 6, 28-38. Retrieved from https://dialnet.unirioja.es/servlet/articulo?codigo $=3920854$

Cervi, D. (2010). The Nanking Massacre and other Japanese military atrocities: the AsiaPacific War, 1931-1945: a curriculum guide for secondary teachers. Trenton, NJ: New Jersey Commission on Holocaust Education.

Chan, K. M. (2009). Harmonious society. International encyclopedia of civil society, 821 825.

China-Japan Relations In The 21ST Century: antagonism despite interdependency. (2018). doi: 10.1007/978-981-10-4373-4

Forty Years in Paradox: Post-normalisation SinoJapanese relations. (2013). China Perspectives, 7-16. doi: 10.4000/chinaperspectives.6314

Forty Years in Paradox: Post-normalisation SinoJapanese relations. (2013). China Perspectives, 7-16. doi: 10.4000/chinaperspectives.6314

Fronza, E. (2018). Memory and punishment: historical denialism, free speech and the limits of criminal law. The Hague: TMC Asser Press.

Gerow, A. (1998). Consuming Asia, consuming Japan: The new neonationalist revisionism in Japan. Bulletin of Concerned Asian Scholars, 30(2), 30- 36. doi: 10.1080/14672715.1998.10411041

Gutenberg. (n.d.). Historical revisionism (negationism). Retrieved from http://www.self.gutenberg.org/articles/eng/historical revisionism (negationism).

Gutenberg. (n.d.). Pseudohistory. Retrieved 17 December, 2019, from http://www.self.gutenberg.org/articles/eng/Pseudohistory.

Herritykm. (2017, 14 September). Critical Reading \& Analysis in History, HIST 3914. Retrieved 5 November, 2019, from https://blogs.lt.vt.edu/criticalreading/2017/09/14/the-essential-practice-ofhistorical-revisionism/.

Historiography of the Asia-Pacific War in Japan. (2008, 3 June). Retrieved 12 February, 2020, from https://www.sciencespo.fr/mass-violence-war-massacreresistance/en/document/historiography-asia-pacific-war-japan\#title1

History.com Editors. (2009, 9 November). Nanking Massacre. Retrieved 8 November, 2019, from https://www.history.com/topics/japan/nanjing-massacre.

In Japan's national interest. (2017, 9 January). Retrieved 8 November, 2019, from https://www.policyforum.net/japans-national-interest/. 
Japan Lodges Protest in Response to Demonstrations in China. (2005, 10 April). Retrieved 6 November, 2019, from https://www.nytimes.com/2005/04/10/international/asia/japan-lodges-protest-inresponse-to-demonstrations-in.html.

Johnson, I., \& Shanker, T. (2012, 16 September). Beijing Mixes Messages Over Anti-Japan Protests. Retrieved 6 November, 2019, from https://www.nytimes.com/2012/09/17/world/asia/anti-japanese-protests-overdisputed-islands-continue-in-china.html.

Johnson, J. (2019, 30 September). Tenuous ties: Few signs of substance behind warming Sino-Japanese relations as communist China marks 70th anniversary. Retrieved 6 November, 2019, from https://www.japantimes.co.jp/news/2019/09/30/national/politicsdiplomacy/tenuous-ties-signs-substance-behind-warming-sino-japanese-relationscommunist-china-marks-70th-anniversary/\#.XcKK00pMTDd.

Kingston, J. (2016). Asian nationalisms reconsidered. London: Routledge, Taylor \& Francis Group. doi: https://doi.org/10.4324/9781315739601

Kolmaš, M. (2018). Identity change and societal pressures in Japan: the constraints on Abe Shinzo's educational and constitutional reform. The Pacific Review, 33(2), 185-215. doi: 10.1080/09512748.2018.1540497

Massachusetts Institute of Technology . (2018). How the Nanjing Massacre Overhauled Japanese Conservatism (pp. 1-13). Retrieved from https://rootpolicy.org/wpcontent/uploads/2018/10/The-Effects-of-Nanjing-Massacre-Revisionism-onJapanese-Conservatism-by-William-Cheng.pd

McCurry, J. (2015, 15 January). Japan urges U.S. publisher to remove comfort women from textbooks. Retrieved 20 February, 2020, from https://www.theguardian.com/world/2015/jan/15/japan-urges-us-publisher-deletereferences-comfort-women

Mochtar Mas'Oed.1994. Ilmu Hubungan Internasional. Disiplin dan Metodologi.Jakarta:LP3ES.Hal.35

Nanjing Massacre-denying Japanese hotel boss sparks Tokyo protest. (2017, 5 February). Retrieved 6 November, 2019, from https://www.reuters.com/article/us-japanchina-hotel-protests/nanjing-massacre-denying-japanese-hotel-boss-sparks-tokyoprotest-idUSKBN15K0GX

Nakano, R. (2018). A failure of global documentary heritage? UNESCOs' memory of the world' and heritage dissonance in East Asia. Contemporary Politics, 24(4), 481-496. doi: 10.1080/13569775.2018.1482435

Nationalism and History in Contemporary Japan. (2016). The Asia-Pacific Journal, 14(20). Retrieved from https://apjif.org/2016/20/Saaler.html

Oh, I., \& Ishizawa-Grbić, D. (2000). FORGIVING THE CULPRITS: JAPANESE HISTORICAL REVISIONISM IN A POST-COLD WAR CONTEXT. International Journal of Peace Studies, 5(2), 45-59. Retrieved 20 February, 2020, from www.jstor.org/stable/41852877

Palgrave Macmillan. (2014). Memory, trauma and world politics: reflections on the relationship between past and. Place of publication not identified. doi: $10.1057 / 9780230627482$

Positive or negative? (n.d.). Retrieved 30 October, 2019, from https://staff.kings.edu/sites/bapavlac/methods/revision.html. 
Refuting Denial. (n.d.). Retrieved 23 February, 2020, from https://www.facinghistory.org/nanjing-atrocities/judgment-memorylegacy/refuting-denial

Remilitarization definition and meaning: Collins English Dictionary. (n.d.). Retrieved 24 January, 2020, from https://www.collinsdictionary.com/dictionary/english/remilitarization

Skoric, Marko \& Beslin, Milivoj. (2017). Politics of memory, historical revisionism, and negationism in postsocialist Serbia. Filozofija i drustvo. 28. 631- 649. 10.2298/FID1703631S.

Stockton, R. (2019, 13 June). WWII Japanese War Crimes So Appalling That The Perpetrators Still Won't Acknowledge Them. Retrieved 30 October, 2019, from https://allthatsinteresting.com/japanese-war-crimes.

Suny, R. (2015, 29 September). Not Even Past: Historical Revisionism and Global Politics. Retrieved 5 November, 2019, from 88 https://www.worldpoliticsreview.com/articles/16809/not-even-past-historicalrevisionism-and-global-politics.

Teo V. (2019) Recalibrating Japan's Foreign Policy. In: Japan's Arduous Rejuvenation as a Global Power. Palgrave Macmillan, Singapore

The Nanjing Massacre. Changing Contours of History and Memory in Japan, China, and the U.S. (2006). The Asia-Pacific Journal, 4(12). Retrieved from https://apjif.org/Takashi-YOSHIDA/2297/article.html

Tokyo, A. F.-P. in. (2016, 14 October). Japan halts Unesco funding following Nanjing massacre row. Retrieved 16 May, 2019, from https://www.theguardian.com/world/2016/oct/14/japan-halts-unesco-fundingnanjing-massacre-row

Transnoodle. (2017, 28 January). The Asian Holocaust Killed Twice As Many People As The Nazis Did. Retrieved 25 November, 2019, from https://medium.com/dose/the-asian-holocaust-killed-twice-as-many-people-as-thenazis-did-877f0a7c664.

University of New Orleans Theses and Dissertations. (2017). New Orleans. Retrieved from https://scholarworks.uno.edu/td/2312

Wei, C. G. (2008). Politicization and De-Politicization of History: The Evolution of International Studies of the Nanjing Massacre. The Chinese Historical Review, 15(2), 242-295. doi: 10.1179/tcr.2008.15.2.242

戦後 50 周年の終戦記念日にあたっての村山内閣総理大臣談話 Prime Minister Tomiichi Murayama "On the occasion of the 50th anniversary of the war's end" (15 August 1995). (n.d.). Retrieved 27 January, 2020, from https://www.mofa.go.jp/announce/press/pm/murayama/9508.html 